Abstract

\title{
The Effect of Lysimachia Savranii on the Migration of the Breast Cancer Cells ${ }^{\dagger}$
}

\author{
Işıl Aydemir 1,*, İsmail Sari 2, Gonca Dönmez 3 , Fatma Esin Kırık ${ }^{4}$, Oktay Özkan 5 , \\ Ahmet Savran ${ }^{6}$ and Mehmet İbrahim Tuğlu ${ }^{7}$ \\ 1 Department of Histology and Embryology, Faculty of Medicine, Niğde Ömer Halisdemir University, \\ 51240 Niğde, Turkey \\ 2 Department of Medicinal Biochemistry, Faculty of Medicine, Niğde Ömer Halisdemir University, \\ 51240 Niğde, Turkey; isari@ohu.edu.tr \\ 3 Department of Medicinal Biology, Faculty of Medicine, Niğde Ömer Halisdemir University, \\ 51240 Niğde, Turkey; gdonmez@ohu.edu.tr \\ 4 Department of Medicinal Microbiology, Faculty of Medicine, Niğde Ömer Halisdemir University, \\ 51240 Niğde, Turkey; fatmaesinkirik@ohu.edu.tr \\ 5 Department of Medicinal Pharmacology, Faculty of Medicine, Niğde Ömer Halisdemir University, \\ 51240 Niğde, Turkey; oktay.ozkan@ohu.edu.tr \\ 6 Department of Arts and Sciences, Faculty of Medicine, Niğde Ömer Halisdemir University, \\ 51240 Niğde, Turkey; asavran@ohu.edu.tr \\ 7 Department of Histology and Embryology, Faculty of Medicine, Manisa Celal Bayar University, \\ 51240 Niğde, Turkey; mituglu@yahoo.com \\ * Correspondence: isilaydemir@ohu.edu.tr; Tel.: +90-388-225-2567 \\ + Presented at the 2nd International Conference on Natural Products for Cancer Prevention and Therapy, \\ Kayseri, Turkey, 8-11 November 2017.
}

Published: 16 November 2017

\begin{abstract}
The treatment of breast cancer includes chemotherapy, radiotherapy and chemotherapy. Recently, alternative agents have been searched for breast cancer, especially medicinal plants because their anti-cancer effects. It has been reported that the genus of Lysimachia has antiproliferative effect on cancer cells. In our study we aimed to evaluate in vitro anti-cancer activity of Lysimachia savranii on migration of breast cancer cells. Breast cancer cell lines MCF-7 and MDA-MB231 and also adipose tissue derived mesenchymal stem cells as normal cells. IC50 doses of Lysimachia savranii extract and Doxorubicin for each cells were calculated via MTT assay. In vitro wound model with $(+)$ plus shape was created using pipette tips for migration analysis and IC50 doses were exposed. The oxidative stress, vascularization and apoptosis were analyzed by immunocytochemical staining of eNOS, iNOS, VEGF and TUNEL. Data was evaluated by Graphpad software using one-way analysis of variance. Lysimachia savranii and Doxorubicin have anti-proliferative effect on breast cancer cells. Breast cancer cell migration was inhibited by Lysimachia savranii. There was an increase of eNOS and iNOS stainings, and apoptotic cells whereas there was a decrease of VEGF staining. Our findings indicate that Lysimachia savranii extract is a potential herbal product for breast cancer therapy.
\end{abstract}

Keywords: Lysimachia savranii; breast cancer; oxidative stress; apoptosis

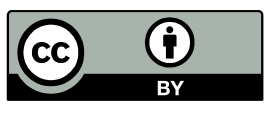

(C) 2017 by the authors. Licensee MDPI, Basel, Switzerland. This article is an open access article distributed under the terms and conditions of the Creative Commons Attribution (CC BY) license (http://creativecommons.org/licenses/by/4.0/). 